\title{
Wiesława Maria Tomaszewska
}

http://orcid.org/0000-0002-2766-7943

Uniwersytet Kardynała Stefana Wyszyńskiego w Warszawie

wtomaszewska@uksw.edu.pl

DOI: $10.35765 /$ pk.2020.2902.09

\section{stylu autobiografii żołnierza-inteligenta (przykład Jana Fudakowskiego)}

\section{STRESZCZENIE}

Artykuł jest efektem badań nad prozą niefikcjonalną, wspomnieniową z czasów wojny 1920 roku. Na podstawie książki autobiograficznej Jana Fudakowskiego Utańskie wspomnienia z roku 1920 autorka rozważa problem swoistości, indywidualności stylu autobiografii wojennej. Jest to autobiografia żołnierza-inteligenta, gdyż Fudakowski konsekwentnie występuje w podwójnej roli, żołnierza i inteligenta, obydwu ważnych w jego widzeniu i sposobach zapisu rzeczywistości wojennej. W świetle narracji autor ujawnia się jako miłośnik prozy Henryka Sienkiewicza, baczny obserwator i uczestnik bitew kluczowych w kampanii wojennej, a także jako obywatel zaangażowany w sprawy niepodległej Rzeczpospolitej. Odsłaniając zrealizowany we wspomnieniach styl autobiografii, autorka podejmuje następujące zagadnienia: (1) styl inteligenckiej tożsamości; (2) styl przedstawiania pól bitewnych; (3) styl myślenia o powojennej przyszłości. Podstawą teoretycznoliteracką rozważań są prace Philippe’a Lejeune'a i Jeana Starobinskiego.

SŁOWA KLUCZE: autobiografia, literatura wspomnieniowa, narracja historyczna, wojna polsko-bolszewicka 1920, ziemiaństwo polskie, inteligencja polska, ułani krechowieccy, Jan Fudakowski

\section{AB STRACT}

On the Autobiographic Style of the Educated Soldier (the Example of Jan Fudakowski)

The article is the result of research into non-fiction, memoir writing from the period of the 1920 war. On the basis of Uhlan Memoirs from 1920, an autobiographical book by Jan Fudakowski, the author considers the problem of specificity and individuality of the war autobiography style. The studied example is an autobiography of a soldier and an educated man. Fudakowski consistently assumes a double role of a soldier and an intelligentsia member, both 
important for his perception and manne of describing the war reality. In the light of his narration, the writer reveals himself as a lover of the prose by Henryk Sienkiewicz, a careful observer and a participant of key battles in the war campaign, and also as a citizen involved in the affairs of the independent Polish Commonwealth. While presenting the autobiographic style of Fudakowski as realized in his memoirs, the author discusses the following thematic orders (systems): (1) the style of intelligentsia identity; (2) the style of presenting battlefields; and (3) the style of thinking about a post-war future. As far as literary theory is concerned, the considerations were based on the works by Philippe Lejeune and Jean Starobinski.

KEYWORDS : autobiography, literary memoirs, historical narration, PolishBolshevik war of 1920, Polish landed gentry, Polish intelligentsia, Krechowce Uhlans, Jan Fudakowski

\section{Osoba piszącego}

Przedmiotem zainteresowania w niniejszym artykule są Utańskie wspomnienia z roku 1920 Jana Fudakowskiego (1901-1982), spisane w roku 1970 z racji 50. rocznicy zwycięstwa nad bolszewikami (Fudakowski, 1971).

Żaden z okresów mego życia nie został utrwalony w pamięci z taką wyrazistością jak kampania wojenna 1920 roku. Mimo że od tych czasów mija pięćdziesiąt lat, przypominam sobie często ówczesne młodzieńcze przeżycia i odszukuję w pamięci poszczególne epizody mojej służby w czwartym szwadronie sławnego 1. Pułku Ułanów Krechowieckich (Fudakowski, 2012, s. 23) ${ }^{1}$.

Zacytowany tu początek wspomnień oddaje zamysł ich narracyjnej całości: „ja” tekstowe chce przekazać wybrane obrazy wysnute z pamięci, scalone $\mathrm{w}$ tekst, oddający punkt widzenia piszącego, czyli 19-letniego peowiaka, ochotnika zmobilizowanego do wojska w grudniu 1919 roku. W wojnie polsko-bolszewickiej Fudakowski walczył przez cztery miesiące, od 27 maja do 23 września 1920, gdy ranny w bitwie pod Ostrogiem został przewieziony pociagiem sanitarnym do warszawskiego szpitala Czerwonego Krzyża na Powiślu (Królikowski, 2012, s. 5-19). Po latach, w stopniu porucznika rezerwy, walczył w kampanii wrześniowej, od 17 września 1939 dowodząc szwadronem ułanów krechowieckich (F 94-95).

1 W niniejszym artykule odsyłacze do tego wydania, ujęte w nawias, wskazują na tekst źródłowy oznaczony literą F (= Fudakowski), a następująca po niej cyfra arabska lokalizuje cytat. 


\section{Literatura „paktu autobiograficznego”}

Jak wyłonić, uwzględniając taksonomie teoretycznoliterackie, nadrzędne cechy tekstowe Utańskich wspomnień...? Przyjmuję, że wspomnienia te, jako proza niefikcjonalna o wojnie polsko-bolszewickiej, stanowią „zbiór całości narracyjnych (można je nazwać substancjami narracyjnymi w sensie Franka Ankersmita) różnego rzędu” (Topolski, 1997, s. 125)². Jest to proza autobiograficzna, świadectwo o rzeczywistości wojennej, przeżywanej zarówno prywatnie (stąd pierwszorzędność „ja” tekstowego), jak i we wspólnocie ułanów krechowieckich (stąd tekstowe „my”). Nawiązując do formuł Philippe'a Lejeune'a, można powiedzieć, że piszący, tworząc literaturę paktu autobiograficznego, posłużył się „retrospektywną opowieścią prozą, gdzie rzeczywista osoba przedstawia swoje życie, akcentując swoje jednostkowe losy, a zwłaszcza dzieje swej osobowości; w prozie tej realizowana jest zasada podwójnej tożsamości, to znaczy autora (którego nazwisko odsyła do rzeczywistej osoby) z narratorem i tożsamości narratora z głównym bohaterem" (Lejeune, 2001, s. 22). Jest to zarazem autobiografia osobista, poprzez którą piszący realizuje, jak by to określił Jean Starobinski, „zamiar przedstawienia serii ważnych wydarzeń, w których autor ukazuje się jako jeden z głównych aktorów" (Starobinski, 2009, s. 87-88).

Przyjmuję więc, że nadrzędną kategorią tekstową wspomnień Fudakowskiego jest autobiograficzność, poddana określonemu ujęciu stylowemu, zrealizowana językowo jako 'dyskurs-historia' ${ }^{3}$, czyli poprzez opowiadanie, w którym „tematem narratora jest jego własna przeszłość, a w którym nadto indywidualne piętno stylu nabiera szczególnego znaczenia" (Starobinski, 2009, s. 84). Owo „indywidualne piętno stylu” uznaję za kluczowe dla Utańskich wspomnień..., w których autor nawiązuje do powszechnie znanych faktów historycznych (jak choćby walki polskich ułanów z armią konną Siemiona Budionnego), ale w swoim tekście autobiograf posługuje się sobie właściwym przekazem, używając określonego „sposobu [ich] przedstawienia, tonacji, rytmu, rozmiarów (...)" (Starobinski, 2009, s. 84).

Dokonując analizy wspomnień ułana-inteligenta ${ }^{4}$, omówię wyodrębnione $\mathrm{z}$ nich zasady stylu, które potwierdzają oblicze własne tychże

2 Autor powołuje się na dzieła Franka Ankersmita, (1983; 1995; 1990, s. 75-104).

3 Wyrażenie 'dyskurs-historia' nawiązuje do É. Benveniste'a, rozróżniającego wypowiedź historyczną, czyli „opowiadanie o czasach minionych”, i dyskurs, czyli „wypowiedź zakładającą mówiącego i słuchacza, a u mówiącego chęć wywarcia w pewien sposób wpływu na słuchacza” (Starobinski, 2009, s. 87).

4 Łącznik użyty w wyrażeniach: 'ułan-inteligent' czy 'żołnierz-inteligent' ma charakter synekdochiczny, integrujący obydwa znaczenia na zasadzie pars pro toto, wskazuje na zintegrowanie podwójności pełnionej przez narratora roli w opowiadanych przezeń wydarzeniach; relacje między obydwoma rzeczownikami mają charakter „relacji wiążących” (zob. Domańska, 2000, s. 29). 
wspomnień. A są to: 1) styl inteligenckiej tożsamości; 2) styl przedstawiania pól bitewnych; 3) styl myślenia o powojennej przyszłości.

\section{Styl inteligenckiej tożsamości}

Pochodzący z rodziny ziemiańskiej Fudakowski w grudniu roku 1919 zgłasza się do wojska jako student I roku Szkoły Głównej Gospodarstwa Wiejskiego w Warszawie. Były uczeń Polskiej Szkoły w Kijowie o swoich kolegach, uczniach starszych, mówi jako o „gotowych zawsze do patriotycznego zrywu w zaraniu odradzającej się Polski” (F 24). On sam podaje inny ważny powód: decyzjotwórczą siłę szlacheckiego obowiązku stawania w obronie Rzeczpospolitej. Przykładem jest dlań śmierć wuja, Konstantego Tarasowicza, który zginął w roku 1918 „w krechowieckich barwach" (F 23), walcząc z bolszewikami w drodze do Bobrujska, gdzie gen. Józef Dowbor-Muśnicki tworzył wojsko polskie.

W Utańskich wspomnieniach... powraca idea, że inteligentów polskich cechuje poczucie odpowiedzialności moralnej za Rzeczpospolitą. Gdy odzyskuje ona niepodległość, inteligencja jak najchętniej bierze na siebie nowe zadania, tworząc państwo polskie od podstaw, tak jak wuj Fudakowskiego Bolesław Kraczkiewicz, mianowany zarządcą Okręgu Podolskiego, który bez wahania podjął wysiłek zorganizowania polskiej administracji na Kresach Rzeczpospolitej. W sytuacji zagrożenia niepodległości w roku 1920, doskonale rozumiejąc wyjątkowość momentu historycznego, inteligenci bez wahania zgłaszają się do wojska. W miarę rozwoju wojennych wydarzeń ci żyjący w dobrobycie ludzie bez skargi znoszą nawet najbardziej uciążliwe warunki wojennego życia, stany skrajnego wyczerpania, brak snu czy pożywienia. Z odrobiną humoru, a już na pewno bez cienia heroizującego patosu, Fudakowski wspomina, jak to on sam - z powodu natłoku wojska i braku kwater - spędził noc w psiej budzie, gdyż innego noclegu we wsi nie mógł znaleźć. Obrazu tego dopełniał rzęsisty deszcz.

Narracja Fudakowskiego uzmysławia inny jeszcze element tożsamości inteligenckiej, a mianowicie nastawienie na szukanie towarzystwa wśród żołnierzy pochodzenia inteligenckiego (czyli najczęściej szlacheckiego), przestawania z ludźmi wykształconymi, bliskimi ideowo, uznającymi ten sam porządek moralny, ten sam system wartości. Inteligenci łączą się w grupy, co przykładowo oddaje słowny drobiazg: „patrol «inteligencki»”. A oto szerszy kontekst słowny tego wyrażenia:

(...) pamiętam trzech starszych ułanów; Stanisława Suchodolskiego, Stasia Zamoyskiego i Janusza Załuskowskiego. Wszyscy byliśmy studentami 
i dlatego w późniejszych wspominkach przezwaliśmy ten patrol „inteligenckim” (F 55).

Przymiotnik dookreślający 'inteligencki’, wzięty w cudzysłów, sugeruje dystans wobec dosłowności sensu wyrażenia, ale oddaje też świadomość chętnego przebywania we wspólnocie, „działającej w sposób wyznaczający inteligencję jako cechę umysłu uzyskaną w wyniku wykształcenia” (Szczepański, 1991, s. 112). Wśród ułanów krechowieckich zawiązują się nowe przyjaźnie, odnawiają dawne, takie, które przetrwają aż po odległe czasy powojenne.

Bywa, że z poczuciem przynależności do inteligencji idzie w parze bogactwo osobowości. Wzmiankowany wyżej Staś, czyli Stanisław Kostka hr. Zamoyski z Zamościa (1899-1939), w Utańskich wspomnieniach... jest jedną z najbardziej wyrazistych osobowości, postacią pozytywną i to nie $\mathrm{z}$ racji arystokratycznego pochodzenia, bo ono w kontaktach z kolegami pozostaje na dalszym planie. Zamoyski jest uosobieniem optymizmu i radości życia. Wyjątkowe zalety jego umysłu ujawniają się w sytuacjach wymagających błyskawicznego działania, umiejętności poradzenia sobie w nowej (w każdej) sytuacji. W twardych realiach wojny (przy stałej obecności wroga) tym jaśniej uwidacznia się jego praktyczność myślenia, zapobiegliwość, troska o potrzeby innych, pomysłowość w zdobywania żywności dla oddziału, a także bezcenna umiejętność porozumienia się z ludźmi z niższych warstw społecznych. Przypominając o tym, Fudakowski tworzy (rozpisany na epizody) portret Zamoyskiego jako najzręczniejszego aprowizatora spośród ułanów krechowieckich. Wspomina z uznaniem, sympatią i wdzięcznością, że „chłopak był przystojny i zawsze uśmiechnięty, potrafił czarować wiejskie baby, które często wynosiły z komory gar mleka i gotowały nam kartofle” (F 53). Postać Zamoyskiego, pozbawiona arystokratycznej hieratyczności, wprowadza do tekstu osobliwą cechę narracji: oscylację między tragizmem wojny a atmosferą pogodnego humoru, dowcipu sytuacyjnego niepozbawionego akcentów zdystansowanej, subtelnej ironii.

Narracja autobiograficzna Fudakowskiego ujawnia wrażliwość na piękno przyrody, pozwalając mu zauważyć zarówno „swoisty dla Ukrainy odurzający aromat” (F 32), jak i, przy nieznacznym obniżeniu tonu, podkreślić również wymierną użyteczność owego piękna. W początkowych partiach tekstu pojawia się obraz krainy niemal idyllicznej, gdy mówi się o tym, że „Kraj był bogaty i, mimo że przednówek się zbliżał, po wsiach wszystkiego było w bród” (F 32) i że „bez trudu można było uzupełniać kotłowe wyżywienie jajami, mlekiem i miodem, których nam miejscowa ludność nie skąpiła” (F 46). Co jednak znamienne: Fudakowskiego interesuje literatura, szczególnie zaś fascynuje go Sienkiewicz, co sprawia, że 
zdania traktujące o kresowych miejscach niezwykłych implikują wzorce Sienkiewiczowskie. A oto przykład: „Kamieniec zrobił na mnie duże wrażenie odwiecznymi murami słynnego zamku. Tchnął atmosferą Sienkiewiczowskiej Trylogii, którą żywo wówczas przeżywałem” (F 27). Istotny jest tu ostatni czasownik, za którym kryje się tryb lektury uwewnętrznionej, „przeżywanej”, czyli takiej, w której atrakcyjność lektury zyskuje wymiar egzystencjalny: spojrzenie na Kresy, na „piękny, stepowy, lekko falisty kraj” (F 31), dokonuje się przez pryzmat prozy historycznej Henryka Sienkiewicza, traktowanej niczym kod kulturowy, gdy literatura uczy słownego wyrażania doświadczeń rzeczywistych. Sienkiewicz to miara literatury wysokoartystycznej, wzorzec literackiej wyobraźni w realizacji tematu wojennego. Znajomość dzieła Sienkiewiczowskiego zrodziła w ułanie-inteligencie postawę wierności literaturze i kulturze ojczystej, osobistego w nie zaangażowania.

Oddziaływanie Sienkiewicza sprawia, że momentami w narracji wspomnieniowej Fudakowskiego uwidacznia się styl artystyczny, będący świadomym naśladownictwem Trylogii, bowiem niektóre epizody (głównie batalistyczne) są tak skonstruowane, jakby sam piszący wręcz przyjmował na siebie rolę Sienkiewiczowskiego narratora. Przestrzeń działań wojennych staje się wówczas uwzniośloną scenerią, na której dokonuje się wskrzeszenie dawnej historii.

Ruszając spod wsi, mieliśmy w oczach widok prawdziwie epiczny. Widzieliśmy z oddali szwadrony pułku (...) szarżujące cwałem na karkach tłumów kozactwa. Na tle krwawo zachodzącego słońca pole bitwy, usłane trupami i rannymi, wyglądało jak żywy obraz dawnych pobojowisk, tylekroć opisanych w Sienkiewiczowskiej Trylogii (F 36).

Jest to opis typowy dla Utańskich wspomnień..., bowiem poszczególne zdania deskryptywne, ich epicki, redundantny rytm, niczym muśnięcia malarskiego pędzla, uniezwyklają przestrzeń, ewokując ducha polskich dziejów. Nawet brzmienie nazw miejscowości mijanych w marszu nasuwa literackie skojarzenia. Fudakowski pisze, że

(...) takie jak Taraszcza, Kahorlik, Skwira, Różyn i wiele innych dźwięczały w uszach Trylogią, a czerwcowe nocne przemarsze i dzienne spotkania z kozactwem wprowadzały prawdziwie Sienkiewiczowski nastrój. Istotnie, śniło nam się czasem, że przeżywamy dalszy ciąg tych odwiecznych dziejów, gdy polskie rycerstwo ukrainne stepy przemierzało (F 46).

Przytoczony fragment trzeba skojarzyć z innym, w którym wspomina się upodobanie żołnierzy do utożsamiania się $z$ postaciami 
Sienkiewiczowskimi. Oto jeden z oddziałów ochotniczych nazwano Chorągwią Laudańską, złożoną z ziemian, z „ludzi różnego wieku, od młodzieńców do pięćdziesięcioletnich starszych panów, [którzy] szli służyć Ojczyźnie krwią i żołnierskim trudem, stanowili dobry, ideowy, pełen fantazji materiał żołnierski” (F 72). Słowo 'ideowy', 'ideał' powraca w narracji wspomnieniowej w odniesieniu do żołnierzy walczących z bolszewikami jako wartość nadrzędna, motywująca podjęcia czynu zbrojnego. Dlatego szlak bojowy ułanów wyznaczają honor i dbałość o godne zachowanie, o przestrzeganie - nawet w najcięższych warunkach polowych zasad dobrego wychowania.

Ale w Utańskich wspomnieniach jest też inny poziom organizacji tekstu, nośnik innego problemu, nie tak uwznioślonego, jak ten dotyczący wpływów Sienkiewicza na kształt narracji. Otóż jeśli w znanym eseju Borys Uspienski zadawał pytanie: „Co to jest inteligencja rosyjska?” i jeśli mówiąc o tej inteligencji, określał jej status jako „zasadniczo odmiennego zjawiska, oryginalnego i specyficznego”, manifestującego się poprzez „rozziew między elitą kulturalną a ludem” (Uspienski, 2001, s. 99), to rozziew ów z rzadka, ale jednak zaznacza się również we wspomnieniach Fudakowskiego. Jasne jest, że inteligencja i chłopi stanowią dwa kontrapunktujące układy społeczne. Z niejakim zakłopotaniem piszący odnotowuje, że w jednej z wsi ukraińskich „Ludność jej przybrała wobec nas wyraźnie wrogą postawę. Owies dla koni trzeba było brać nieledwie siłą. Poza tym okazało się, że w stodołach było dużo ukrytej broni, włącznie z karabinami maszynowymi” (F 31). Zaraz jednak skwapliwie dodaje, że był to ,jedyny wypadek tak wrogiego nastawienia, bowiem ukraińska ludność witała nas raczej przychylnie i z dodatkowym jedzeniem na kwaterach” (F 31). Może autor, sam życzliwy chłopom, nie ulegał ich wrogości? Może nie chciał utrwalać na piśmie bolesnych wspomnień? A może zachował w pamięci jedynie przychylność kobiet wiejskich względem arystokraty Zamoyskiego? Trudno rozstrzygnąć.

\section{Styl przedstawiania pól bitewnych}

W omawianych wspomnieniach dominuje autorska postawa uważnej analizy kampanii wojennej, by z sekwencji wydarzeń (bo wydarzeniowość jest jedną $z$ reguł epickiego przedstawiania) wydobyć fragmenty najbardziej znaczące. Model narracji batalistycznej Fudakowskiego - opowiadanie sprawozdawcze, gęsto poprzetykane epizodami bezpośrednich starć z wrogiem, któremu przyświeca „wierność reminiscencji” (Starobiński, 2009, s. 88) - cechuje naprzemienne tempo wydarzeń. Czas bitewny reguluje zasada kontrastu, jest bowiem czas względnego spokoju, odpoczynku 
i czas walki, czas intensywnego napięcia, stania w szyku bojowym w oczekiwaniu na bezpośrednie starcie z wrogiem. Ta druga sytuacja, maksymalnych napięć psychicznych, ujawnia wojnę jako potężną siłę destrukcyjną i dezintegrującą, nie darmo w relacjach batalistycznych Fudakowski sięga po symboliczne słowa klucze, 'ogień', 'krew' i 'śmierć'.

Ogień to „krzyżowy ogień taczanek z kozackich skrzydeł, silny ogień taczanek, ogień bolszewickiej strzelaniny, ogień (...) celny, granaty rwały się gęsto, ponieśliśsmy znaczne straty w ludziach i koniach” (F 68). Obrazom nieprzerwanego, huraganowego ognia towarzyszy nieprzewidywalne tempo wydarzeń, gdy szala wygranej przechyla się raz na stronę bolszewików, raz na stronę polskich szwadronów, które mają przed sobą „masy bolszewickiej jazdy” (F 44). Co jednak charakterystyczne - w Utańskich wspomnieniach... zasadniczo pomija się milczeniem obrazy bolszewickich okrucieństw. I choć krew i śmierć są wszechobecne, to wojenna opowieść o cierpieniach i śmierci unika drastycznych, makabrycznych szczegółów. Posługuje się najczęściej określeniami pośrednimi, uogólniającymi tragizm jednostkowych sytuacji, jak na przykład: „Pułk mocno się skrwawił. Straty w rannych i zabitych koniach były też znaczne” (F 36), „pamiętam jedynie krwawe pobojowisko” czy „oddział zmniejszył się o połowę" (F 52). Być może tę postawę samoograniczania się tłumaczy wskazana wyżej odległość czasowa pomiędzy wydarzeniami a ich zapisem, wszak styl autobiografii jest uwarunkowany „teraźniejszością aktu pisania [będąc] wynikiem marginesu swobody, jaką dają język i konwencja literacka, oraz sposobu wykorzystania go przez piszącego" (Starobiński, 2009, s. 84). Fudakowski przywołuje nieliczne obrazy krwi kwoli wiarygodności przekazu, dlatego, że przynależą one do fenomenu wojny. $\mathrm{Na}$ przykład zapamiętał kolegę ułana, „zalanego krwią, ale wciąż na koniu”, gdy „ktoś go podtrzymywał i prowadził do punktu opatrunkowego” (F 35). A równocześnie zauważył znaczący mechanizm psychiczny: przyzwyczajenie się żołnierzy do widoku ludzkich okaleczeń, do stałego przebywania w pobliżu ludzkich zwłok. Obok „krwawego pobojowiska” pod Kilikijowem ${ }^{5}$ on sam spokojnie mógł „przegryzać suchary”, stwierdzając, że „zobojętnienie na widok pobojowiska było całkowite” (F 52). W stwierdzeniu tym nie ma obwiniania ani siebie, ani innych. Brak żywej reakcji na śmierć jest efektem przywyknięcia do takich widoków. Niemniej udział w wojnie budzi w piszącym świadomość popełniania złych czynów. Ale oto zapis zaskakującego doświadczenia, uchwytującego, zda się, moment fascynacji wojną mimo doświadczenia jej grozy.

5 Kilikijow (Kilikijew, Kylykyiv), dziś ukraińska wieś, położona między Zwiahlem a Równem, w II Rzeczpospolitej w województwie wołyńskim. 
Kto nie przeżywał emocji kawaleryjskiego spotkania, ten nie jest w stanie wyczuć uniesienia i zapamiętania, jakie odczuwa szarżujący jeździec. Nerwy grają w najwyższym napięciu, uczucie strachu mija, a koń niesie pełnym galopem, rozgrzany zapamiętaniem jeźdźca, czasem rozwścieczony, gotów tratować i zębem zahaczyć (F 41).

Zarazem jednak - mimo akceptacji TEJ wojny, gdyż ze strony polskiej jest to walka z bolszewikami na śmierć i życie o niepodległość Ojczyzny w narracji przebłyskują rozterki moralne, dotyczące zadawania śmierci wrogom w obronie życia własnego i kolegów. O jednym z ułanów Fudakowski mówi wprost, że „niejednego bolszewika miał na sumieniu” (F 42). Dodaje jednak, że wyrafinowane okrucieństwo zadawane ułanom przez bolszewików, „wprowadzało w naszych szeregach zaciętość i chęć zemsty” (F 47). Wspomnienia wielu autorów z wojny 1920 roku podkreślają ten znamienny moment: wielką nienawišć bolszewików do polskich ułanów.

Intensywność osobistych doświadczeń bitewnych powoduje, że żołnierz nawet po wielu latach pamięta dźwięki z pola walki, dlatego Utańskie wspomnienia... niosą zapisy wrażeń dźwiękowych, towarzyszących bitewnemu zgiełkowi („usłyszeliśmy z oddali odgłos rozgrywającej się bitwy i szybko podążaliśmy w tym kierunku”, F 35). Wysubtelniony słuch ułana nie tylko odróżnia brzmienie natarcia od brzmienia defensywy, ale rozpoznaje również używany przez wroga rodzaj broni. A jeśli z nagła zapadnie cisza, słyszy nawet „dźwięk gryzionego przez konie wędzidła” (F 50). Żołnierz jest kimś, kto dźwięku kul, bitewnej codzienności, słucha niby muzyki sfer, stąd frazy: „kule śpiewały ze wszystkich stron”, kule dźwięczą, kule świszczą, „ścinając liście i drobne gałęzie z drzew przydrożnych nad naszymi głowami” (F 33). Rzadkie są momenty ciszy, ale Fudakowski i to zapamiętał, że w głębokiej ciszy, niemal absolutnej, odbyło się brawurowe wyjście polskich ułanów z bolszewickiego okrążenia pod Równem, w bliskości bolszewików, ot, na wyciągnięcie ręki. W obliczu niebezpieczeństwa śmierci cichną ludzie i konie.

Co oczywiste: jednym z istotnych doświadczeń ułana jest zachowanie się jego konia, przyjaciela i nieodstępnego towarzysza. Narrator zapamiętuje tupot końskich kopyt po drewnianych mostkach, doskonale wyczuwa niepokój, nerwowość koni przed walką, mówi o bolesnym przeżywaniu ich ciężkich zranień i śmierci. Ułan zżywał się ze zwierzęciem, zranienie konia czy jego utrata były odczuwane niemal tak samo, jak śmierć współtowarzysza. Ułańskie wspomnienia... z wojny roku 1920 przekonują, że ważną rolę w wojnie 1920 odegrały również konie, boleśnie ranione, mordowane, silnie odczuwające głód i strach, a mimo to częstokroć ratujące ułana od niechybnej śmierci. Ułan zachowywał wrażliwość na piękno koni, nawet bolszewickich, bolał nad ich zaniedbaniem. 
Szczytem kampanii polsko-bolszewickiej, jej przełomem i we wspomnieniach ułańskich Fudakowskiego, i w opracowaniach historyków, jest bitwa pod Komarowem, bitwa kawalerii polskiej z 30 sierpnia 1920 roku, określana przez historyków jako „ostatni wielki bój kawalerii” (Stachnik, 2019). Jest to finalna bitwa w wojennej biografii wojennej autora Utańskich wspomnień...,

(...) najsławniejsza kawaleryjska bitwa kampanii 1920 roku, gdyż w tym dniu, w całodziennych zmaganiach z naszą 1. Dywizją Jazdy, Armia Konna została pokonana i zmuszona do odwrotu. Po komarowskiej bitwie Budionny już nie stawiał nam czoła, wymykał się i na wschód uchodził. Było to poza tym ostatnie spotkanie wielkich jednostek jazdy na miarę napoleońskich wojen, gdzie biała broń i ogień artyleryjski na wprost decydowały o zwycięstwie (F 78).

Z przebiegu linii fabularnej wynika, że był to „pamiętny dzień (...) w którym ułan zapominając o zmęczeniu i głodzie, był gotów na wszystko, nie myśląc o życiu” (F 78). Relację z tej bitwy piszący przekazuje z punktu widzenia „skromnego wówczas szeregowego” (F 74), jak sam się określa. Dlatego ogranicza się do „ogólnych wrażeń i kilku żywiej zapamiętanych epizodów” (F 74). Był obserwatorem tej bitwy, oglądanej z odległego wzgórza, bo tam stał jego macierzysty szwadron ułanów oczekujący na sygnał wejścia do akcji. Wielogodzinne stanie w odwodzie pozwala mu, niczym widzowi, uczestniczyć w swoistym theatrum bitwy, widzieć całość: polską kawalerię i jej przeciwnika, „chmary Kozaków i ich tabory” (F 75). Patrząc z oddalenia, poczynił spostrzeżenie niezwykłe: bitwa nie jest chaosem, lecz rytmem, porządkiem, układem przewidywalnych reguł. Jako obserwator uchwycił zasadę manewrowania masami wojsk, ich naprzemienne przesuwanie się to naprzód, to w tył, pod ciągłym ogniem bolszewickiej artylerii. „Gdy granaty [bolszewickie - W.T.] zaczęły nas coraz bliżej obramowywać, nasze ławy cofały się stępem, w porządku, bądź tė̇ posuwały się ku przodowi” (F 75). Ten wahadłowy rytm, jednostajny i monotonny ruch, budzi wrażenie obrzędowej niemal, choć niezamierzonej teatralizacji, malowniczości „choreograficznego" układu. Po kilkugodzinnym trwaniu na wzgórzu, skutkiem napięcia nerwów i zmęczenia, a nawet znudzenia, rodzi się w obserwatorze zniecierpliwienie: „to manewrowanie wydawało się trwać bez końca” (F 75). Szwadron Fudakowskiego włączono wreszcie do bitwy, ale, co wynika z relacji, jego udział w bezpośrednim starciu z bolszewikami trwało krótko:

Goniliśmy ławę kozacką do pobliskiego lasku, a gdy już zaczęliśmy ich rąbać na dobre, zwykłym sobie manewrem Kozacy rozjechali się przed 
laskiem w dwie strony i odsłonili taczanki. Dostaliśmy się pod gęsty ogień karabinów maszynowych (F 76).

Wówczas został ciężko ranny plutonowy Zenon Witkowski, dla Fudakowskiego kończy się komarowska bitwa, ratuje kolegę, przewożąc sparaliżowanego ułana do lazaretu ${ }^{6}$.

Po bitwie pod Komarowem przeżywał jeszcze ofensywną szarżę nocną z 2 na 3 września 1920 w okolicy Łaszczowa ${ }^{7}$, pod nieprzerwanym ogniem karabinów maszynowych wobec „tyraliery nacierającej bolszewickiej piechoty” (F 82). Tym razem Fudakowski jest niezwykle czynny w walce, co przekazuje komentarz o reportażowej wręcz dokładności:

Kłułem lancą wielokrotnie, waliłem po łbach tych, co poddać się nie chcieli, a w pewnej chwili przerzuciwszy lancę do lewej ręki z wodzami, wydobyłem mój pistolet - Colta potężnego kalibru, i wystrzelałem magazynek do końca (F 83).

Znamienny rzeczowy szczegół: ten colt był własnością kuzyna, Wojciecha Kunickiego, poległego na froncie litewsko-białoruskim podporucznika piechoty (F 83), broń tę Janowi przed wyjazdem na front przekazała matka zmarłego.

Fudakowski świadom jest tragicznych skutków wojny. Jeszcze w trakcie jej trwania zdaje sobie sprawę z konieczności odbudowania własnego życia duchowego. Pragnie przywrócić kulturę-w-sobie, po wojennym prowizorium chce powrócić do świata cywilizacji. Wyrazem jej zagubienia jest język, którym mimowiednie się posługuje, język potoczny, dosadny, nieuchodzący inteligentowi. Do języka tego, kierowanych do wroga „soczystego repertuaru (...) przekleństw, wyzwisk i gróźb” (F 34), przywykł na froncie. Gdy przez zapomnienie użył go w towarzystwie kobiet, wzbudził swoje i ich zażenowanie, ale także „pobłażliwą wyrozumiałość”. Po takich doświadczeniach autor wspomnień narzuca sobie postawę wzmożonej autorefleksji, powracając do życia przeżywanego z całą siłą czujnej, nadwrażliwej niekiedy świadomości.

6 Zenon Witkowski, kawaler Krzyża Virtuti Militari, zmarł na początku listopada 1920 roku w Szpitalu Mokotowskim w Warszawie. Fudakowski, też wówczas ranny, był jedynym z oddziału kolegą odwiedzającym go w szpitalu, następnie uczestniczącym w jego pogrzebie. Z wielkim żalem zanotował, że „śmierć była dla niego wyzwoleniem, gdyż cierpiał bardzo, a rany były beznadziejne, gdy w dodatku przyszła gangrena” (F 77).

7 Miejscowość położona w Lubelskiem, w powiecie tomaszowskim. 


\section{Styl myślenia o powojennej przyszłości}

Jak wyżej podkreślono, znaczny dystans czasowy pomiędzy wydarzeniami wojennymi a ich spisaniem rodzi osobliwość sytuacji narracyjnej, gdy w stylu autobiografii odzwierciedla się „aktualna autoreferencja”, będąca "odbiciem chwili pisania, aktualnego «ja»" (Starobiński, 2009, s. 308). Dlatego myśli Fudakowskiego, stanowiąc „tajemne połączenie minionego z przyszłym, (...) wzajemny związek (...) wspomnienia i nadziei” (Koselleck, 2012, s. 361), krążą wokół duchowego i moralnego odrodzenia niepodległej Polski. Projektodawczość w narracji zajmuje miejsce poboczne, myśli, które określam jako projektodawcze, uobecniane są wyłącznie explicite. A oto niektóre spośród nich:

1) odnowić lub odbudować wysoką kulturę materialną, świat „przedmiotów kultury" (określenie Wilhelma Diltheya), widomy znak wartości duchowych. Jeśli przyjąć, że elementem typowym postawy inteligenta jest jego stosunek do kultury (Szczepański, 1991, s. 120), to narracyjnym constans jest zagłada dóbr kultury, obrazy sprofanowanych książek i całych bibliotek, zniszczonych kolekcji dzieł sztuki i innych cennych przedmiotów. Narratora nawet po latach zadziwia skala oglądanych zniszczeń, zaciekłość w masakrowaniu Piękna. Tak działali bolszewicy. Zbrukane Piękno przegrywało w starciu z barbarzyństwem. Fudakowski jest przekonany, że niszczenie Piękna to miara słabości zbolszewiczałego człowieka;

2) kształcić młodzież, która powinna podjąć przerwaną naukę, co zresztą stało się faktem, gdyż „po wojnie z bolszewikami (...) niemal cała zwolniona $z$ wojska młodzież akademicka wróciła na studia w mundurach" (F 95). Fudakowski wybrał studia rolnicze, by w postawie społecznej użyteczności administrować rodowym majątkiem;

3) podtrzymać w Polsce jedność narodową, tę z okresu najazdu bolszewików. We wspomnieniach pojawia się zdanie niezwykłe, jak bowiem twierdzi piszący, podczas wojny polsko-bolszewickiej „Wszyscy: księża, ziemianie, nauczyciele, drobna szlachta, chłopi katoliccy - byli nam szczerze życzliwi i sprawie polskiej oddani” (F 36). A jeśli tak, to należy przeciwdziałać wszelkim formom społecznego rozbicia;

4) wierzyć w sens porządku nadprzyrodzonego; otwierając się na nieskończoność Bożo-ludzkiej rzeczywistości, Fudakowski wspomina modlitwę na Jasnej Górze przed udaniem się na front, a ocalenie życia z wojennej pożogi tłumaczy opieką Matki Boskiej Częstochowskiej. Po czasie tragedii wojennych przyszedł czas na wdzięczność, także wobec drugiego człowieka, który pomógł przetrwać. 


\section{Zakończenie}

„Jeżeli uchem przypadniemy do polskiej ziemi, zewsząd dojdzie nas tętent kopyt końskich, a ziemia cała, jak Polska długa i szeroka, dudnić będzie pod tupotem ustawicznych szarż” (Machalski, 1969, s. 7). Fudakowski jest jednym spośród wielu autorów wspomnień o wojnie 1920 roku. Zwykle ujawniają się w nich losy konkretnych jednostkowych bohaterów, ale także tłumów żołnierskich, niemniej wspólnym bohaterem prozy tego kręgu jest polski homo militans. Dlatego polskie teksty wspomnieniowe, takie jak Utanskie wspomnienia... Fudakowskiego, otwierają rozległe pole badań historycznych i kulturoznawczych, antropologicznych i literaturoznawczych, jeśli przyjąć, że każdy tekst wspomnieniowy ma również znaczenie dla badań narratywistycznych, dla których każda narracja jest interpretacją, a tym bardziej narracja autobiograficzna. „Wszelka autobiografia (...) jest autointerpretacją”, jak twierdzi Starobinski (2009, s. 85). Pozornie prosta (i w miarę jednoznacznie przekazana) opowieść Fudakowskiego bez wątpienia przydaje wieloznaczeniowości temu wydarzeniu dziejowemu, którym w polskiej historii XX wieku była wojna polsko-bolszewicka 1920 roku.

\section{BiBLIOGRAFIA}

Ankersmit, F. (1983). Narrative Logic. A Semantic Analysis of the Historian's Language. Boston-London: The Hague.

Ankersmit, F. (1990). Narracja jako przedstawianie. W: J. Pomorski (red.), Metodologiczne problemy narracji historycznej. Lublin: Wydawnictwo Uniwersytetu Marii Curie-Skłodowskiej, 75-104.

Ankersmit, F. (1995). Statements, Texts and Pictures. W: F. Ankersmit i H. Kellner (red.), The New Philosophy of History. Chicago: University of Chicago Press, 212-240.

Domańska, E. (2000). Wokół metahistorii. W: H. White, Poetyka pisarstwa historycznego. Red. E. Domańska i M. Wilczyński. Kraków: Towarzystwo Autorów i Wydawców Prac Naukowych „Universitas”, 7-31.

Fudakowski, J. (1971). Ułańskie wspomnienia z 1920 r. Przeglad Kawalerii i Broni Pancernej. Kwartalnik Historyczny, nr 62 (kwiecień-czerwiec).

Fudakowski, J. (2012). Utańskie wspomnienia z roku 1920. Do druku przygotował i wstępem poprzedził B. Królikowski. Lublin: Towarzystwo Naukowe Katolickiego Uniwersytetu Lubelskiego Jana Pawła II.

Kosselleck, R. (2012). Semantyka historyczna. Wybór i oprac. H. Orłowski, tłum. W. Kunicki. Poznań: Wydawnictwo Poznańskie. 
Królikowski, B. (2012). Wstęp. W: J. Fudakowski, Utanskie wspomnienia z roku 1920. Lublin: Towarzystwo Naukowe Katolickiego Uniwersytetu Lubelskiego Jana Pawła II, 5-19.

Lejeune, Ph. (2001). Pakt autobiograficzny. Tłum. A. Labuda. W: R. Lubas-Bartoszyńska (red.), Wariacje na temat pewnego paktu. O autobiografii. Kraków: Towarzystwo Autorów i Wydawców Prac Naukowych „Universitas", 21-55.

Machalski, T. (1969). Ostatnia epopeja: dziatania kawalerii w 1920 roku. Londyn: B. Świderski.

Stachnik, P. (2019). Bitwa pod Komarowem. Ostatni wielki bój kawalerii. Pozyskano z: https://naszahistoria.pl/bitwa-pod-komarowem-ostatni-wielki-boj-kawalerii/ar/10644542, 2014 (dostęp: 30.10.2019).

Starobinski, J. (2009). Styl autobiografii. Tłum. W. Kwiatkowski. W: M. Czermińska (red.), Autobiografia. Gdańsk: Wydawnictwo Słowo/Obraz Terytoria, 83-97.

Szczepański, J. (1991). Inteligencja. W: A. Kłoskowska (red.), Pojęcia i problemy wiedzy o kulturze. Wrocław: Wiedza o Kulturze, 111-126.

Topolski, J. (1997). Czy historyk maluje przeszłość? Wokół koncepcji F. Ankersmita i N. Goodmana. W: R. Kubicki i P. Zeidler, P. (red.), Od logiki do estetyki. Poznań: Wydawnictwo Fundacji Humaniora, 117-126.

Uspienski, B. (2001). Inteligencja rosyjska jako fenomen kultury rosyjskiej. W: B. Uspienski, Religia i semiotyka. Tłum. B. Żyłko. Gdańsk: Wydawnictwo Słowo/Obraz Terytoria, 97-108, przypisy: 156-159.

Wiesława Maria Tomaszewska - profesor nadzwyczajny na Wydziale Nauk Humanistycznych UKSW. Autorka artykułów naukowych i popularnych oraz trzech książek: Między ideq a rzeczywistościq. Andrzeja Kijowskiego wizja literatury (Warszawa 2002), Andrzej Kijowski: biografia - bibliografia - recepcja. Studium dokumentacyjne (Warszawa 2005) i Metafizyczne i religijne. Problem subtematu $w$ dziele literackim na przyktadzie prozy kresowej Wtodzimierza Odojewskiego (Warszawa 2011). Redaktor sześciu tomów serii wydawniczej „Studia o Kijowskim” (Warszawa 2001-2016). 